\title{
THE EU REGULATORY ACTIVITIES IN THE AREA OF DIGITAL PLATFORMS AND SERVICES PROVISION
}

\author{
Kosjenka Dumančić, PhD, Associate Professor \\ Faculty of economics and business \\ Trg J. F. Kennedy 6, Zagreb, Croatia \\ kdumancic@efzg.hr
}

\begin{abstract}
New and innovative ways of service provisions based on digital platforms have changed the ways in which doing business, communicating and connecting providers to users in the EU Internal Market are shaped and transformed. Since the adoption of the Directive 2000/31/EC (the E-Commerce Directive) in 2000 digital services have gained market dominance, and this has become especially evident during the Covid-19 virus crisis when the importance of digital technologies in all aspects of modern life became prominent. It has clearly shown the dependency of the economy and the society on digital services highlighting both the benefits and the risks that stem from the current framework for the functioning of the services provided by the digital platforms regardless of whether they are defined as digital services or not.
\end{abstract}

In the European Commission (EC) Communication "Shaping Europes Digital Future" the EC committed to update the horizontal rules that define the responsibilities and obligations of digital service providers, and online platforms in particular. Additionally, the European Parliament's "Report on the Digital Services Act and fundamental rights issues posed" highlights the need for legal clarity of platforms and users, as well as respect for fundamental rights in the light of the rapid development of technology.

According to the current data, the digital platforms account for over $10 \%$ of the EU's 45 million users. These platforms are subject not only to the specific obligations in controlling their own risks, but also to a new oversight structure.

In 2020 the EC initiative was finalized by the "Proposal for a Regulation on a Single Market for Digital Service" which addresses the negative consequences arising from certain behaviours on platforms. Since the EU Internal market is impacted significantly by platforms that serve as intermediaries for business users to reach their customers, sometimes these companies assume control over the entire platform ecosystems, which in turn can grant them the opportunity to regulate certain relations. The controlling power comes from the practices that platform companies exercise and from using the data of the businesses and users operating on these platforms. 
This paper aims to analyse the current regulation on digital platforms and digital service provisions in the EU Internal Market and offer some conclusions on its possible impact on the market's functioning especially in the times of the Covid-19 pandemic and subsequently.

Keywords: digital services, regulation, EU Internal market, digital platforms, Covid-19

\section{INTRODUCTION}

The digital society is characterised by four specific features: the irrelevance of geographical location, the key role of the platforms, the importance of connectivity and the use of big data. ${ }^{1}$ These features differentiate the digital market from the traditional one, especially as a result of the transformation of the associated value chain. ${ }^{2}$ Technology is part of everybody's daily life, which this creates a vital framework for all modern economic sectors and raises the importance of the digital market and information society services. This importance was recognized in the European Commission Digital Single Market Strategy ${ }^{3}$ that was created to facilitate the free movement of persons, services and capital in situations where the individuals and businesses can seamlessly access and exercise online activities under conditions of fair competition while providing a high level of consumer and personal data protection, irrespective of their nationality or place of residence. ${ }^{4}$

It should be noted that the Digital Single Market Strategy was one of the first strategic documents of the European Commission that dealt with digitalisation. This document was preceded by the E-commerce ${ }^{5}$ and Services ${ }^{6}$ directives, which no longer corresponded with the rapid progress of technology especially the mobile phones and the implementation of roaming facilities in Europe. Consequently, the existing regulation was not in line with the provision of certain services, espe-

$1 \quad$ Charrié J.; Janin L., Ficalité du numérique Le numérique: comment réguler une économie sans frontière?, La note d'analyse 35, Paris, France Stratégie, 2015, Vol. 90, No. 7-8, pp.67-73, available from [https:// archives-gfp.revuesonline.com/article.jsp?articleId=37983], Accessed 1 May 2021.

2 Valenduc, G.; Vendramin, P., Work in the digital economy: sorting the old from the new, European Trade Union Institute, Working paper 2016.03, 2016, p. 7.

3 Communication from the Commission to the European Parliament, the Council, the European Economic and Social Committee and Tthe Committee of The Regions A Digital Single Market Strategy for Europe, Brussels, 6.5.2015, COM(2015) 192 final (The Digital Single Market Strategy).

4 Frosio; G. F., Reforming Intermediary Liability in the Platform Economy: A European Digital Single Market Strategy, 112 NW. U. L. REV. ONLINE 18 (2017-2018), pp. 19-46 .

5 Directive 2000/31/EC of the European Parliament and of the Council of 8 June 2000 on certain legal aspects of information society services, in particular electronic commerce, in the Internal Market, OJ L 178, 17.7.2000, p. 1-16 (Directive on electronic commerce).

6 Directive 2006/123/EC of the European Parliament and of the Council of 12 December 2006 on services in the internal market, OJ L 376, 27.12.2006, p. 36-68 (Services directive). 
cially those provided through digital platforms. ${ }^{7}$ As a reaction to the fast development of digital platforms, the need for the new regulatory framework arose.

The aime of this paper is to analyse the current regulatory framework on digital platforms and digital service provisions in the EU Internal Market and offer some conclusions on its possible impact on the market's functioning in the light of new regulatory package proposed by the European Commission in the year 2020. Paper is devided into 6 chapters including Introduction and Conclusion. Chapter 2 gives an overview of the exsisting regulation on the digital services. In chapter 3 suggestions for the future research are presented. Chapter 4 analyses the specific characteristics of digital services accentuating the difference between information society services and others based on the analysis of the rulings of the Court of Justice of the European Union (further CJEU). Finaly, in chapter 5 the new regulatory framework for the digital services is presented.

\section{OVERVIEW OF THE EXISTING REGULATION ON THE DIGITAL SERVICES}

The European Commission has adopted a series of documents highlighting the digital economy as one of the European Union's priorities. In 2010, The European Commission adopted the Digital Agenda for Europe ${ }^{8}$ with the aim to enable the economy and the citizens of the European Union to achieve their maximum by using digital technologies. The importance of the digital economy is clear from the title of the document and elaborated in the subtitle "Restarting the European economy," which highlights the priority goal: to enable citizens and businesses to make the best use of digital technologies. As stated in the Digital Agenda, "The Internet has no borders, but its market, both globally and in the European Union, is still divided by multiple restrictions." These restrictions result from different national legislations governing, inter alia, certain areas that pertain to the field of digital economy.

The Digital Agenda has enabled further development of legislation in the field of digital economy at the level of the European Union and its implementation in national legislations. Its aim is to maximize the sociological and economic potential of information technology, especially the Internet in the areas of business, work, games, communication and free expression. The goal is to increase innovation and

Juncker, J. C.: Extract from the Political Guidelines for the next European Commission - A New Start for Europe: My Agenda for Jobs, Growth, Fairness and Democratic Change (15 July 2014).

8 Communication from the European Commission to the European Parliament, the Council and the European Economic and Social Council and the Council of the Regions: A Digital Agenda for Europe, COM (2010) 245, Brussels, 19.5.2010 ( The Digital Agenda). 
economic growth, and thus improve everyday life for citizens and businesses. In order to achieve these goals, it is necessary to harmonize national legislations and introduce a common regulatory framework at the level of the European Union. It is believed that future developments will lead to more efficient use of digital technology by enabling the EU to address the key challenges and enhance the Europeans' quality of life through improved healthcare, safer and more efficient transport, cleaner environment, new media opportunities, and easier access to public services and cultural content. ${ }^{?}$

In 2014 the European Commission engaged its efforts to "make better use of the great potential of digital technologies that know no borders, and in order to do so it is necessary to have the courage to overcome national obstacles in the field of telecommunications regulations, copyright regulations and data protection, radio wave management and the application of competition rules." ${ }^{10}$ As a result of this initiative, European Commission Communication "The Digital Single Market Strategy for Europe" ${ }^{11}$ was adopted in 2015 in order to enable the implementation of internal market rules on the four freedoms, as the result of a need for introducing a single strategy that will include not only the "physical" - internal market but also the digital market.

The Digital Single Market Strategy for Europe ushered a number of documents adopted by the European Commission in 2016 that encourage the use of digital technologies and lay the foundation for future regulation. The Communication on online platforms and the Digital Single Market ${ }^{12}$ was adopted. It introduced the sound regulatory framework for the digital economy, which will contribute to the promotion of sustainable development and the development of business models for platforms in Europe. ${ }^{13}$ Harmonized rules at the EU level, such as the General Data Protection Regulation ${ }^{14}$ and the Network and Data Security Directive, ${ }^{15}$

$9 \quad$ Ibid., pp. 3.

10 Policy Guidelines for the New European Commission - A New Beginning for Europe: My Agenda for Employment, Growth, Justice and Democratic Change, 15.7.2014.

11 The Digital Single Market Strategy, op.cit., note 3.

12 The Communication from the Commission to the European Parliament, the Council, the European Economic and Social Council and the Council of the Regions: Online Platforms and the Digital Single Market Opportunities and Challenges for Europe (COM (2016) 288 final, Brussels, 25.5.2016.

$13 \quad$ Ibid., pp. 4.

14 Regulation (EU) 2016/679 of the European Parliament and of the Council of 27 April 2016 on the protection of natural persons with regard to the processing of personal data and on the free movement of such data, and repealing Directive 95/46/EC (Text with EEA relevance) OJ L 119, 4.5.2016, p. 1-88 (General Data Protection Regulation).

15 Directive (EU) 2016/1148 of the European Parliament and of the Council of 6 July 2016 concerning measures for a high common level of security of network and information systems across the Union, 
extend the applicable rules to the online platforms and above. It also pointed out that online platforms are subject to the existing EU rules in the areas such as competition, consumer protection, personal data protection and single market freedom, and that harmonization of all the related platforms with these rules is crucial to ensure fair competition for all participants, thus developing the confidence of companies and the general public in working with online platforms.

At the same time, the need to define the collaborative economy, which began to grow in the European Union market together with a number of digital platforms, was recognized. As the first step towards the regulation, the Commission's Communication under the title "A European agenda for the Collaborative Economy was adopted. ${ }^{16}$ Subsequently, the Digital Single Market Strategy ${ }^{17}$ preceded the adoption of the Joint Declaration on the EU's legislative priorities for 2018-19, ${ }^{18}$ outlining the political responsibility of the EU institutions to complete the key legislation in the Digital Single Market by the end of 2017. To achieve these goals, the Communication emphasizes that the European Union's strength is based on fully integrated internal market and open global economic system. One of the most important goals of the Communication in relation to the regulatory framework is to promote the cooperation of regulatory bodies around the world. This goal clearly indicates that the digital economy has no physical boundaries, and that regulation must take this into account, as neither national nor local regulations alone can meet all the requirements set by this form of economy. Then the Commission issued a Communication on "Creating a Common European Data Space" ${ }^{19}$ which makes recommendations for further regulation on the use of data in the Internal Market. Apart from these strategic documents, the European Union has adopted a number of regulations and directives. ${ }^{20}$

\section{OJ L 194, 19.7.2016, p. 1-3.}

16 Communication from the Commission to the European Parliament, the Council, the European Economic and Social Committee and the Committee of the Regions A European agenda for the collaborative economy, COM/2016/0356 final, Brussels, 2.6.2016. (Agenda for the collaborative economy).

17 Communication from the Commission to the European Parliament, the Council, the European Economic and Social Committee and the Committee of the Regions on the mid-term review of the implementation of the Digital Single Market Strategy (Digital Single Market for All) (Brussels, COM (2017) 228 final 10.5.2017).

18 European Commission Joint Declaration on the EU's legislative priorities for 2018-19, 17.12.2017.

19 The Communication from the Commission to the European Parliament, the Council, the European Economic and Social Committee and the Committee of the Regions: Creating a Common European Data Space (COM (2018) 232 Final Brussels, 25.4.2018.

20 The most important of which are Regulation (EU) 2019/1150 of the European Parliament and of the Council of 20 June 2019 on promoting fairness and transparency for business users of online intermediation services, 186, 11.7.2019, pp. 57-79, General Data Protection Regulation, op. cit., note 14, Directive (EU) 2015/1535 of the European Parliament and of the Council of 9 September 2015 laying 


\section{DIRECTIONS FOR FURTHER REGULATION}

The described legal framework does not fully meet the needs of regulating the services provided through the platforms that have experienced a significant increase in recent times. The digital platforms and the collaborative economy are regarded as the most controversial parts of the Digital Single Market regulatory framework. ${ }^{21}$ Such rapid development of platforms that competed with traditional service providers has caused disruptions at the European as well as at the national and local levels, and inputs were gathered from different stakeholders, such as civil society, associations, trade unions and others. ${ }^{22}$ The Agenda for the Collaborative economy introduced the 'problem' of the digital platformisation after the situation at the local level regarding the application of the European and national laws escalated. The discussion that followed the rulings of the CJEU revolved around the right to restrict the activities of platform service providers Uber and Airbnb in certain member states.

When searching for the applicable legal regime for the collaborative economy the applicability of the internal market freedoms has to be provided, especially regarding the service provisions. Besides the provision of services, the freedom of movement of workers should also be discussed by addressing and differentiating between service providers who act as workers, ${ }^{23}$ self-employed ${ }^{24}$ persons, or just as peers ${ }^{25}$ providing services as their second job, free to decide on their working hours ${ }^{26}$ and considering themselves as independent contractors who wish to earn some extra income. This includes the question of the character of the service itself and the role of the platform.

The freedom to provide services within the EU law was primarily based on the idea of free movement of persons across the border in order to provide services in another member state or in order to receive them in a different member state. The

down a procedure for the provision of information in the field of technical regulations and rules on information society services (codified text) (OJ L 241, 17.9.2015, p. 1-15), Directive on services in the internal market, op.cit. note 6; Directive on electronic commerce, op. cit., note 5.

${ }^{21}$ Adamski, D.: Lost on the digital platforms:Europe's legal travails with the digital single market, Common Market Law Review, Vol. 55, No. 3, 2018, pp. 719-751.

22 Inglese, M., Regulating the collaborative economy in the European Union Digital Single Market, Springer, 2019. p. 41.

23 Valenduc; Vendramin, op.cit., note 2.

24 Todoli-Signes, A.: The "gig economy:" employee, self-employed or the need for a special employment regulation, ETUI, I-13, 2017, pp. 5-6.

25 Bauwens, M.; Niaros, V., The emergence of peer production: challenges and opportunities for labour and unions, ETUI Policy Brief European Economic, Employment and Social Policy, no 3/2017, pp. 2.

26 Inglese, op.cit., note. 22, pp. 45. 
cross border element in these transactions exsists in particulary in the movement of persons in order to provide or to receive the service. The third way or realising this freedom was the possibility to provide or receive a service without crossing the border in situations when the service was provided by specific means, such as the Internet or phone. This form of the service provision is especially accentuated in the digital economy which is supported by digital platforms. The freedom to provide services, just like other market freedoms, could be restricted by the national legislation with specific justifications that are established by the EU primary and secondary law. The requirement of licensing for specific activities and professions occurred as one of the limitations to the free service provisions. When discussing the freedom to provide services, the question of classification of services arises. In this regard, the definition of the service provided by the platform was questioned. In order to answer to the question of the character of the service, the service providers should also be analysed since in some cases the platforms were offering the services themselves while in others there were merely the intermediaries.

The Agenda for the Collaborative Economy identifies the platforms as the intermediaries that connect providers with users, and facilitate transactions between them. The first communication that was issued by the Commission in $2015^{27}$ defines online platforms as "software-based facilities offering two- or even multi-sided markets where providers and users of content, goods and services can meet." 28 Nevertheless, the Pandora's Box was opened when it became clear that platforms play different roles in this tripartite relation among service providers, service users, and platforms as intermediary facilitators. ${ }^{29}$ It was clear that platforms have outgrown their roles of meagre intermediaries in many cases.

\section{ANALYSIS OF THE INFORMATION SOCIETY SERVICE IN CJEU JUDGMENTS}

Information Society services are defined in Article 1(2) of Directive 98/34/EC ${ }^{30}$ as "any service normally provided for remuneration, at a distance, by electronic

27 Commission staff working document A Digital Single Market Strategy for Europe - Analysis and Evidence Accompanying the document Communication from the Commission to the European Parliament, the Council, the European Economic and Social Committee and the Committee of the Regions A Digital Single Market Strategy for Europe, COM(2015) 192 final, SWD (2015) 100 final.

28 Ibid., pp. 2.

29 Newlands, G.; Lutz, C.; Fiesler, C., Power in the sharing economy: European Perspectives, Report from the EU H2020 Research project Ps2Share: Participation, Privecy and Power in the Sharing Economy, 2017.

30 Directive 98/34/EC of the European Parliament and of the Council of 22 June 1998 laying down a procedure for the provision of information in the field of technical standards and regulations and of rules on Information Society services, OJ L204 of 21 July 1998. 
means and at the individual request of a recipient of services." The analysis of this definition of information society services requires clarification of the meanings of the terms. It refers to the service provided by electronic equipment and at individual request of the service user without the participants' concurrent presence at the same location. ${ }^{31}$

According to Directive 2000/31/EC on certain legal aspects of information society services in the EU internal market, in particular in e-commerce, no national measure on market access requirements should be discriminatory. ${ }^{32}$ Under the existing EU law, service providers may be subject to market access requirements if such requirements are justified and proportionate. This assessment is made by the CJEU considering the specifics of each particular business model..$^{33}$

In order to clarify which law is applicable regarding the service provided by a platform, the Court of Justice of the European Union (CJEU) undertook the examination of Uber company service. ${ }^{34}$ The Uber cases ${ }^{35}$ were the first to be analysed pursuant to the applicable EU law and its restrictions that were enacted by the national and regional authorities in predominantly tourism-orientet countries Spain and France. ${ }^{36}$

The main question is whether the service, which is referred to as collaborative economy service, is also an information society service ${ }^{37}$ and, if so, whether such activities are protected under the EU law to provide services freely or under the national law of a specific sector of the Member State in which they operate. To reach a decision on this issue, it is necessary to analyse the activity of the platform and the connection of the electronic and non-electronic elements of their business. In the case of composite services, ${ }^{38}$ i.e. services involving electronic and non-electronic elements, a service can be considered to be entirely provided by

31 Opinion of the AG Szpunar in case C-434/15 Asociación Profesional Elite Taxi v Uber Systems Spain, 2017.

32 Hatzopoulos, V., The collaborative economy and EU law, Hart publishing, Oxford, 2018, pp. 31-32.

33 Smorto G. in Goniadis, A., Collaborative economy, European Parlament. DG for internal policies, 2017.

34 Davidov, G., The status of Uber drivers: A Purposive approach, Hebrew University of Jerusalem Legal studies Research Paper Series No. 17-7 to be published in the Spanish Labour law and Employment Relations Journal. 2017; Adams Prassl, J., Pimlico plumbers, Uber drivers, cycle couriers and court translators: who is a worker? Law Quarterly Review, 2017.

35 Domurath, I., Platforms as contract partners: Uber and beyond, Maastricht Journal of European and Comparative Law, Vol. 25, No. 5, 2018, pp. 565-581.

36 Case C-434/15 Asociación Profesional Elite Taxi v Uber Systems Spain, ECLIC:EU:C:2017:981.

37 Hatzopoulos, op. cit., note 35, pp. 33.

38 Sousa Ferro, M., Uber Court: a look at recent sharing economy cases before the CJEU, UNIO - EU Law Journal, Vol. 5, No.1, 2019, pp. 68-75. 
electronic means when the supply, which is not provided by electronic means, is economically independent of the service provided by those means. This is particularly the case when the intermediary service provider facilitates commercial relations between users and independent service providers. An example of this case may be the platforms for airline tickets or hotel reservations as in these cases; the intermediary service has real value added for the consumer and trader. ${ }^{39}$

When service provider delivers the same services both on and off-line, it is necessary to establish the main conceptual component in economic terms. In order for a service to qualify as an information society service, its main element must be performed by electronic means. When the conclusion of the contract and the payment, are carried out by electronic means they should be covered by the definition of information society services. The delivery of the purchased goods is only a fulfilment of the contractual obligation with the intent that the provision on such delivery does not affect the provision of the principal service. In the case of composite services, consisting of electronic and non-electronic elements, the former should be economically independent in relation to the latter in order to be considered an information society service. ${ }^{40}$

According to the European Union's legislation, platforms are exempt from liability for providing the information that they store under certain circumstances. The applicability of this exemption will depend on legal and factual circumstances, and according to the Art. 14 of the EU E-Commerce Directive, platforms will be exempt from liability when providing hosting services. By definition, hosting services represent the activities that are passive, technical and automatic, which implies that the information society service provider has neither knowledge of nor control over the transmitted or stored information.

The first Uber case against Spain started as a complaint about the infringement of the national Spanish law and unfair competition practiced by Uber drivers in Barcelona in relation to the 'regular' taxi drivers associated in the professional association of taxi drivers. At that time, Uber was just beginning to gain its market share as an innovative platform business model that connected service providers (drivers) and consumers. The main difference between the Uber drivers and the 'traditional taxi drivers' was their membership in the professional association. The provision of taxi services provided by the Uber platform includes the connection between the drivers and passengers ${ }^{41}$ in real time through the smartphone application, and the payment facilities which was also supported by the platform. Unlike

\footnotetext{
39 Opinion AG Szpunar, op. cit, note 34

40 Ibid.

41 Schaub, M.Y., Why Uber is an information society service, EuCML 3(2018), pp. 109-115, p. 113.
} 
the traditional business model, this one had a platform that acted as an intermediary between the driver and the passenger.

In order to provide taxi services in Barcelona, one had to be a professional driver and a member of the professional taxi drivers' association, holding an appropriate licence or authorisation for delivering taxi services. The number of taxi drivers was limited by law and their activity was monitored by the local authorities. Providing taxi services supported by the Uber platform ${ }^{42}$ caused disturbance in the taxi service market of Barcelona and the main question for CJEU was whether the national restrictions proposed to the Uber service providers were justified. Therefore, the character of the service itself was discussed. According to the CJEU, an intermediation service that enables the transfer, by means of smartphone application, of information concerning the booking of a transport service between the passenger and the non-professional driver using his/her own vehicle in principle meets the criteria for classification as an information society service. However, with regard to the service itself and its purpose, it is obvious that it's the goal to drive persons from one place to another is identical to that of that of the taxi service.

Consequently, the CJEU undertook the assessment of the character of the Uber service and concluded that it connects passengers with drivers offering non-public urban transport services similarly to taxi transport. Therefore, it is classified as the service in the field of transport and, according to the Services Directive, this field is exempt from this directive and hence from the rules of the Internal market on free movement. ${ }^{43}$ Hence, the CJEU concluded that the intermediation service provided by Uber must be regarded as an integral part of the overall service whose main component is transport, and therefore has to be classified as a "service in the field of transport" and not as an "information society service." ${ }^{44}$ The justification for this reasoning features two arguments: firstly, without Uber platform there would be no transport service, and secondly, Uber has a decisive influence over the conditions under which the service is provided. ${ }^{45}$ The case of Uber followed the same path in France. ${ }^{46}$

In its Uber Spain and Uber France judgements, the CJEU refers only to the service's intermediation as "integral part of an overall service whose main component

\footnotetext{
42 Guda, H., Subramanian, U., Your Uber is arriving: managing on-demand workers through surge pricing, forest communication and workers Incentives, Management science, Vol. 65, No.5, 2019.

43 Article 58(1) TFEU.

44 Case C-434/15, op. cit., note 32, para. 38 .

45 Case C-434/15, op. cit, note 32, para. 39.

46 Case 320/16 Criminal proceedings against Uber France [2018] ECLI:EU:C:2018:221.
} 
is transport service." ${ }^{47}$ By relying on its earlier case-law CJEU interprets what is meant by the concept of services in the field of transport and by analysing the definition of information society service which main part is to be provided "by electronic means." 48

At the same time, CJEU examined a case in the accommodation sector. ${ }^{49}$ It concerned Airbnb, ${ }^{50}$ a digital platform connecting the providers and recipients of short term accommodation services. ${ }^{51}$ The French court (Tribunal de grande instance de Paris) has lodged the preliminary reference to the CJEU asking, primarily, whether the services provided in France by Airbnb Ireland via its electronic platform, which is operated from Ireland, are included in the freedom of services granted by Article 3(2) of Directive 2000/31/EC (E-commerce directive). ${ }^{52}$

Again, the status of the 'information society service' was discussed. Airbnb is an online platform for accommodation services that connects hosts and guests who are looking for accommodation. This position was raised since in the Uber cases it was clear that if the service itself could be classified as the information society service' the EU law shall apply. ${ }^{53}$ Whereas, in the judgment on the Airbnb Ireland case the CJEU followed the Opinion of AG Szpunar, ${ }^{54}$ the legal status of this platform was evaluated differently from the previous judgements in the Uber cases. ${ }^{55}$ According to the European Commission, a case-by-case analysis ought to be performed in order to set the legal nature of the platform's activities. The enduring legal uncertainty surrounding the aforesaid definition is the case of Airbnb, an online platform that does not provide a service by itself but is still deemed a professional trader.

$47 \quad$ Case C-434/15, op. cit., note 32, para. 40.

48 A service is provided by electronic means if it is "sent initially and received at its destination by means of electronic equipment for the processing (including digital compression) and storage of data, and entirely [emphasis added] transmitted, conveyed and received by wire, by radio, by optical means or by other electromagnetic means" (Article 1(1)(b)(ii) of Directive 2015/1535).

49 Case 390/18 Criminal proceedings against X [2019] ECLI:EU:C:2019:1112 (Airbnb Ireland).

50 Busch, C., The Sharing economy at the CJEU: Does Airbnb pass the "Uber test"? EUCML, Issue 4/2018, 2018. pp.172-174.

51 Guttentag, D. A., Why tourists choose Airbnb: A motivation-based segmentation study underpinned by innovation concepts. Thesis. Waterloo Ontario Canada. 2016.

52 Case 390/18, op. cit., note 49.

53 In short, the Uber cases excluded the possibility of applying of the EU law since its service was classified as a transport service and therefore exempt from the application of the EU law. The idea in the Airbnb case was to defend the thesis that the platform provides a different service than Uber and that the EU law should apply.

54 Case 390/18, op. cit., note 49, Opinion AG Szpunar.

55 Case 526/15 Uber Belgium BVBA v Taxi Radio Bruxellois NV [2016] ECLI:EU:C:2016:830; Case 434/15 op. cit., note 32; Case 320/16, op. cit. note 46. 
The main dilemma for the CJEU in the Airbnb Ireland case ${ }^{56}$ was whether the Services Directive applies to the Airbnb service, or if it is to be qualified as an information society service, within the meaning of Art 2(a) of E-Commerce Directive, as amended by the Information Society Services Directive. Under Art 1(1) (b) of Information Society Services Directive, the concept information society service covers "any service normally provided for remuneration, at a distance, by electronic means and at the individual request of a recipient of services."

Relating to the question of whether the Airbnb service is provided 'at a distance' and 'by electronic means,' AG Szpunar illustrated his point as for Airbnb Ireland does not physically meet the recipients of its services: neither the hosts nor the guests. As is apparent from the preliminary observations concerning Airbnb Ireland's activities, the host is not required to approach Airbnb Ireland in person in order to publish his/her accommodation on the platform. Furthermore, the user of the platform managed by Airbnb Ireland may rent accommodation at a distance and need not be in physical contact with the service provider. However, it is clear that the connection of users of the platform managed by Airbnb Ireland results in using the accommodation, which may be regarded as a non-electronic component of the service provided by that company. ${ }^{57}$

Following the Opinion of AG Szpunar, CJEU found that the Airbnb Ireland intermediation service meets the four cumulative conditions provided in Art 1(1) (b) of Information Society Services Directive, and thus constitutes an information society service' within the meaning of E-Commerce Directive. ${ }^{58}$ Moreover, the CJEU determined that the Airbnb Ireland intermediation service cannot be regarded as forming an integral part of overall service, the main component of which is the provision of accommodation..$^{59}$

Interestingly, in its judgment the CJEU also made a distinction between Airbnb and Uber. In the Airbnb Ireland judgment, the CJEU stated that the case against Airbnb Ireland was unlike the case against Uber, as it cannot be established that Airbnb Ireland has a 'decisive influence' over the conditions for the provision of the accommodation services to which its intermediation service relates. ${ }^{60}$ This differentiation is also in accordance with the European Commission idea that each sector should be regulated by specific 'tailor-made' regulation.

\footnotetext{
56 Coyle, D.; Yeung, T.Y-C., Understanding AirBnB in Fourteen European cities, The Jean-Jacques Laffont digital chair, Working papers, 2017.

57 Case 390/18, op. cit., note 49, Opinion of AG Szpunar, para 41.

58 Ibid., para 49.

$59 \quad$ Ibid., para 57.

$60 \quad$ Ibid., para 68.
} 
Namely, Airbnb does not determine the rental price charged for the property and allows buyers to choose which house to rent. In contrast, Uber sets the price for the ride in its application and assigns a driver to each passenger. The analysis of the policy document shows that significant documents and recommendations in the area of collaborative economy exist, but that significant issues remain that require consideration. ${ }^{61}$

Just like Uber, this business model has also provoked tectonic changes in the hospitality industry: the emergence of Airbnb has resulted in its opening virtually to any homeowner. The downside is that the profitability of short-term holiday rentals has an adverse effect on the housing markets as it reduces the number of available long-term housing at affordable prices. ${ }^{62}$ This concern has led many communities to impose strict(er) rules on short-term rentals. ${ }^{63}$ It was concluded that the accommodation sector is governed by "a range of pre-existing regulatory frameworks which have not been tailored to the collaborative economy".

\section{NEW REGULATORY FRAMEWORK FOR THE DIGITAL PLATFORMS}

The aforementioned situation regarding the regulation of the digital platforms resulted in more intensive activity of the European Commission and other European institution. In June 2019, the European Parliament and the Council introduced the Regulation on promoting fairness and transparency for business users of online intermediation services. ${ }^{64}$ It introduces ${ }^{65}$ new rules on transparency and disclosure for service providers and the business users or corporate website users that should be established in the Union and consumers located in the Union. The entities required to comply with this regulation shall be liable to disclose any competitive advantage that their products enjoy over the competitors, as well as explain how the data is collected, distributed, and used. ${ }^{66}$ As the result of the application of this regulation, online platforms and search engines will have to disclose the main parameters used to rank goods and services on their site. The regulation

${ }_{61}$ Goudin P, The Cost of Non-Europe in the Sharing Economy: Economic, Social and Legal Challenges and Opportunities, European Parliamentary Research Service, 2016, pp. 106.

62 European Commission, Study on the assessment of the regulatory aspects affecting the collaborative economy in the tourism accommodation sector in the 28 Member States, 580/PP/GRO/IMA/15/15111J, 2018, pp. 154 .

63 OECD, Policies for the tourism sharing economy, OECD Tourism Trends and Policies. 2016. Chapter 3.

${ }_{64}$ Regulation (EU) 2019/1150, op. cit., note 20.

65 Ibid., recital 9.

66 Ibid., Article 1. 
is not applicable to business to consumer relationship, which leads to application of the consumer protection rights regarding the users of the digital platforms.

In 2020 the European Commission activities in this area flourished. Namely, besides this regulation on setting new rules on digital space, the Commission proposed two documents as future regulations indicating the way forward for regulating the digital business: the Digital Services Act (DSA ${ }^{67}$ and the Digital Markets Act (DMA) ${ }^{68}$ Both Acts resulted from the reaction to the developing digital market and Internet activities. Since the 2000 e-Commerce Directive ${ }^{69}$ and the 2006 Service Directive, the legal regime for services and online services did not change, except for the CJEU practice. Consequently, the European Commission committed to update the horizontal rules publishing Communication Shaping Europe's Digital Future ${ }^{70}$ in February 2020.

The DSA develops the internal market principle established by the E-Commerce Directive and is complementary to the e-Platform-to-Business Regulation (EU) 2019/1150 (the P2B Regulation), effective from July 2020, and to the Directives that were adopted as part of the New Deal for Consumers, effective by May 2022.

The problem of competition between digital and 'regular' markets and their distinction is recognized when a platform is at the same time a platform and a competitor to other businesses within that platform. In order to classify the importance and adequate reaction to the importance and influence of each digital platform four levels of providers of the information society services are recognized: providers of intermediary services, hosts and online platforms providers, online platforms, and very large online platform providers.

The second proposal, the Digital Markets Act (DMA) addresses digital market imbalances in the EU and introduces a new term: 'gatekeeper' platforms. These platforms are defined as large online platforms which meet a set of criteria established by the European Commission and aim to secure that certain unfair practices by 'gatekeeper' platforms shall be prohibited. In order to define the "gatekeeper companies" the European Commission established a set of criteria that have to be met: strong economic and intermediation position and stability over time.

67 Proposal for a Regulation of the European Parliament and of the Council on a Single Market for Digital Services and amending Directive 2000/31/EC, COM/2020/825 final (Digital Services Act).

68 Proposal for a Regulation of the European Parliament and of the Council on contestable and fair markets in the digital sector COM/2020/842 final, (Digital Markets Act).

69 Directive 2000/31/EC, op.cit., note 5.

70 Communication from the Commission to the European Parliament, the Council, the European Committee and the Committee of the Regions Shaping Europe's digital future COM/2020/67 final. 
It is necessary to emphasise that the two documents are not entirely aligned. The notion of 'gatekeeper' used by DMA does not correspond to the DSA's notion of 'very large online platforms'. For instance, a platform with more than 45 million monthly active end users established or located in the EU will be considered a very large online platform under the DSA, but it will need to meet all three criteria mentioned above to be designated as the gatekeeper under the DMA.

\section{CONCLUSION}

The DSA and DMA package is believed to be the driver of the changes of the ways ompanies offer and use digital services in the EU. Primarily, it will refer to large companies primarily, but it will also include the companies with a strong impact on the market.

The DSA goes further than consolidation and harmonisation. It contains many provisions that could help protect the users' fundamental rights, improve the transparency and accountability of internet platforms, and raise the awareness of contractual connections. The proposed transparency obligations should be deemed positive, especially for internet intermediaries, online platforms, and very large online platforms. The text of the proposed documents clearly demonstrates that the reasoning of the CJEU was taken into consideration and implemented into the regulatory act. These documents support the requirements that emphasized the need for regulation over analyses that imposed self-regulation. However, the application of DSA to business users will still leave a gap in relation to nonbusiness users (regular non-professional consumers) who are the major users of these platforms. It is to be expected that the provider-platform-consumer triangle service will have to wait for the new round of regulatory activity. Until then the self-regulation and activity of the CJEU will apply. The DSA and DMA need to be examined conjointly in order to reach the final and the optimal solution for all the existing business models and for those that are yet to come.

\section{REFERENCES}

\section{BOOKS AND ARTICLES}

1. Adams Prassl, J., Pimlico plumbers, Uber drivers, cycle couriers and court translators: who is a worker?, Law Quarterly Review,Vol. 133, No.3, 2017, pp. 366-376

2. Adamski, D., Lost on the digital platforms:Europes legal travails with the digital single market, Common Market Law Review, Vol. 55, No. 3, 2018, pp. 719-751

3. Busch, C., The Sharing economy at the CJEU: Does Airbnb pass the "Uber test"?, EUCML, Issue 4/2018, 2018, pp.172-174 
4. Coyle, D.; Yeung, T.Y-C., Understanding AirBnB in Fourteen European cities, The JeanJacques Laffont digital chair, Working papers, 2017

5. Davidov, G., The status of Uber drivers: A Purposive approach, Hebrew University of Jerusalem Legal studies Research Paper Series No. 17-7 to be published in the Spanish Labour law and Employment Relations Journal. 2017

6. Domurath, I., Platforms as contract partners: Uber and beyond, Maastricht Journal of European and Comparative Law, Vol. 25, No.5, 2018, pp. 565-581

7. Frosio, G. F., Reforming Intermediary Liability in the Platform Economy: A European Digital Single Market Strategy, 112 NW. U. L. REV. ONLINE 18 (2017-2018), pp. 19-46

8. Goudin P., The Cost of Non-Europe in the Sharing Economy: Economic, Social and Legal Challenges and Opportunities, European Parliamentary Research Service, 2016

9. Guda, H.; Subramanian, U., Your Uber is arriving: managing on-demand workers through surge pricing, forest communication and workers incentives, Management science, Vol. 65, No.5, 2019, pp.1995-2014

10. Guttentag, D. A., Why tourists choose Airbnb: A motivation-based segmentation study underpinned by innovation concepts, Thesis. Waterloo Ontario Canada, 2016

11. Hatzopoulos, V., The collaborative economy and EU law, Hart publishing, Oxford, 2018

12. Inglese, M., Regulating the collaborative economy in the European Union Digital Single Market, Springer, 2019

13. Juncker, J. C., Extract from the Political Guidelines for the next European Commission - A New Start for Europe: My Agenda for Jobs, Growth, Fairness and Democratic Change (15 July 2014)

14. Newlands, G.; Lutz, C.; Fiesler, C., Power in the sharing economy: European Perspectives, Report from the EU H2020 Research project Ps2Share: Participation, Privecy and Power in the Sharing Economy, 2017

15. OECD, Policies for the tourism sharing economy, OECD Tourism Trends and Policies, 2016

16. Schaub, M.Y., Why Uber is an information society service, EuCML 3(2018), pp. 109-115

17. Smorto G. in Goniadis, A., Collaborative economy. European Parlament. DG for internal policies. 2017

18. Sousa Ferro, M., Uber Court: a look at recent sharing economy cases before the CJEU. UNIO EU Law Journal. Vol. 5, No.1, 2019, pp. 68-75

19. Todoli-Signes, A., The "gig economy": employee, self-employed or the need for a special employment regulation, ETUI, I-13, 2017, pp. 5-6

20. Valenduc, G.; Vendramin, P., Work in the digital economy: sorting the old from the new, European Trade Union Institute, Working paper 2016.03, 2016

\section{EU LAW}

1. Commission Communication to the European Parliament, the Council, the European Economic and Social Council and the Council of Regions: European Agenda for the Sharing Economy, 356, Brussels, 2016

2. Communication from the Commission to the European Parliament, the Council, the European Economic and Social Committee and The Committee of The Regions A Digital Single 
Market Strategy for Europe, Brussels, 6.5.2015, COM(2015) 192 final (Digital Single Market Strategy)

3. Communication from the Commission to the European Parliament, the Council, the European Economic and Social Committee and the Committee of the Regions on the mid-term review of the implementation of the Digital Single Market Strategy, Brussels, COM (2017) 228 final 10.5.2017, (Digital Single Market for All)

4. Communication from the Commission to the European Parliament, the Council, the European Committee and the Committee of the Regions Shaping Europe's digital future $\mathrm{COM} / 2020 / 67$ final

5. Communication from the Commission to the European Parliament, the Council, the European Economic and Social Council and the Council of the Regions: Online Platforms and the Digital Single Market Opportunities and Challenges for Europe, COM (2016) 288 final, Brussels, 25.5.2016

6. Communication from the Commission to the European Parliament, the Council, the European Economic and Social Committee and the Committee of the Regions Creating: A Common European Data Space, COM (2018) 232 Final Brussels, 25.4.2018.

7. Communication from the European Commission to the European Parliament, the Council and the European Economic and Social Council and the Council of the Regions: A Digital Agenda for Europe, COM (2010) 245, Brussels, 19.5.2010

8. Directive (EU) 2015/1535 of the European Parliament and of the Council of 9 September 2015 laying down a procedure for the provision of information in the field of technical regulations and rules on information society services (codified text), OJ L 241, 17.9.2015, p. $1-15$

9. Directive (EU) 2016/1148 of the European Parliament and of the Council of 6 July 2016 concerning measures for a high common level of security of network and information systems across the Union, OJ L 194, 19.7.2016, p. 1-3

10. Directive 2000/31/EC of the European Parliament and of the Council of 8 June 2000 on certain legal aspects of information society services, in particular electronic commerce, in the Internal Market ('Directive on electronic commerce'), OJ L 178, 17.7.2000, p. 1-16

11. Directive 2006/123/EC of the European Parliament and of the Council of 12 December 2006 on services in the internal market, OJ L 376, 27.12.2006, p. 36-68

12. Directive 98/34/EC of the European Parliament and of the Council of 22 June 1998 laying down a procedure for the provision of information in the field of technical standards and regulations and of rules on Information Society services, OJ L204 of 21 July 1998

13. European Commission Joint Declaration on the EU's legislative priorities for 2018-19, 17.12.2017

14. Policy Guidelines for the New European Commission - A New Beginning for Europe: My Agenda for Employment, Growth, Justice and Democratic Change, 15.7.2014

15. Proposal for a Regulation of the European Parliament and of the Council on a Single Market For Digital Services and amending Directive 2000/31/EC (Digital Services Act)

16. Proposal for a Regulation of the European Parliament and of the Council on contestable and fair markets in the digital sector, COM/2020/842 final (Digital Markets Act) 
17. Regulation (EU) 2016/679 of the European Parliament and of the Council of 27 April 2016 on the protection of natural persons with regard to the processing of personal data and on the free movement of such data, and repealing Directive 95/46/EC, OJ L 119, 4.5.2016, paragraphs 1-88 (General Data Protection Regulation)

18. Regulation (EU) 2019/1150 of the European Parliament and of the Council of 20 June 2019 on promoting fairness and transparency for business users of online intermediation services. 186, 11.7.2019, pp. 57-79

\section{COURT OF JUSTICE OF THE EUROPEAN UNION}

1. Case 320/16 Criminal proceedings against Uber France [2018] ECLI:EU:C:2018:221

2. Case 390/18 Criminal proceedings against X [2019] ECLI:EU:C:2019:336, Opinion of AG Szpunar

3. Case 390/18 Criminal proceedings against X [2019] ECLI:EU:C:2019:1112 (Airbnb Ireland)

4. Case 526/15 Uber Belgium BVBA v Taxi Radio Bruxellois NV [2016]ECLI:EU:C:2016:830

5. Case C-434/15 Asociación Profesional Elite Taxi $v$ Uber Systems Spain [2017] ECLIC:EU:C:2017:981

\section{WEBSITE REFERENCES}

1. Bauwens, M.; Niaros, V., The emergence of peer production: challenges and opportunities for labour and unions, ETUI Policy Brief European Economic, Employment and Social Policy, no 3/2017. Available from [https://www.etui.org/sites/default/files/Peer\%20production $\% 20$ Bauwens\%20Niaros\%20Policy\%20Brief\%202017.03.pdf], Accessed 1 June 2021

2. Charrié J.; Janin L., Ficalité du numérique Le numérique: comment réguler une économie sans frontière?, La note d'analyse 35, Paris, France Stratégie, 2015, Vol 90 No. 7-8, pp. 67-73. Available from [https://archives-gfp.revuesonline.com/article.jsp?articleId=37983], Accessed 1 May 2021 